\title{
Heterosis and genetic parameters for yield and nutritional components in half-sibling maize progenies
}

\author{
I.R. Carvalho ${ }^{1}$, A.J. de Pelegrin ${ }^{1}$, M. Ferrari ${ }^{1}$, V.J. Szareski ${ }^{1}$, T.C. da Rosa ${ }^{1}$, \\ V.F. de Oliveira ${ }^{1}$, J.F. Hoffmann ${ }^{1}$, M. Nardino ${ }^{1}$, G.G. Conte ${ }^{1}$, F.C. Chaves ${ }^{1}$, \\ V.Q. de Souza ${ }^{2}$, A.C. de Oliveira ${ }^{1}$, L.C. da Maia ${ }^{1}$ \\ ${ }^{1}$ Federal University of Pelotas, Capão do Leão, RS - Brazil. \\ ${ }^{2}$ Federal University of Pampa, São Gabriel, RS - Brazil. \\ Corresponding author: I.R. Carvalho \\ E-mail: carvalho.irc@gmail.com
}

Genet. Mol. Res. 17 (4): gmr18024

Received May 15, 2018

Accepted October 02, 2018

Published October 03, 2018

DOI http://dx.doi.org/10.4238/gmr18024

\begin{abstract}
The growing demand for maize creates a challenge for breeders; they need to constantly develop higher yielding and higher quality genotypes. We estimated the most relevant genetic parameters, along with heterosis and variance components. A multivariate approach was used in order to define profiles of narrow sense heritability for yield and nutritional components in half-sibling maize progenies. The applied experimental design was random blocks with a male parent (hybrid tester), five inbred lines $\left(\mathrm{S}_{5}\right)$ as maternal parents and the progenies (hybrid Top Cross), totaling 11 maize genotypes arranged in six replicates. Agronomic and nutritional characters were evaluated. Half-sibling progenies revealed greater additive genetic contribution to phenotypic expression with grain width and thickness, iron content, total flavonoids and carotenoids, soluble solids, and methionine. Narrow sense heritability values between and within progenies were higher for manganese content, glycine, proline and tryptophan. Regardless of the $\mathrm{S}_{5}$ inbreeding line used, heterosis gains were obtained for ear insertion height, number of grain rows per ear, stalk diameter, zinc content, total carotenoids, soluble solids and $\mathrm{pH}$. Specific heterosis was found
\end{abstract}


for grain yield, glycine, serine, threonine and phenylalanine. The multivariate analysis defined eight profiles of traits according to their genetic tendencies, and indicated narrow sense heritability of the progeny mean as the main reason for this classification.

Key words: Zea may; amino acids; nutritional profile of grains; breeding; biofortification

\section{INTRODUCTION}

Maize (Zea mays) is a cereal cultivated worldwide that has agricultural, economic and social impact. It is consumed as food and fed to domestic animals and also provides raw material for industrialized products (Wen et al., 2016; Szareski et al., 2018). The growing demand for maize is a constant challenge for breeders, requiring the development of higher yielding and higher quality genotypes (Ufazand Calili, 2008). Breeding is crucial to increase maize yield; conventional breeding techniques make use of the available germplasm and hybridization and selection strategies are used to develop the agronomic ideotypes desired by the breeder. However, in order to find high potential genotypes, it is necessary to understand the additive genetic fraction responsible for phenotype expression and thus, to determine the inheritable fraction of the character in the progenies.

When only phenotypic measures are available, genotypic inferences are obtained through the use of genetic designs and biometric techniques. When these tools are properly used, it is possible to partition the total variation into phenotypic and genotypic variance components in order to obtain the genetic parameters necessary to explain the heritable tendencies and to direct select (Falconer and Mackay, 1996).

In order to improve target traits, maize breeding programs seek superior hybrid combinations, supported by efficient selection of the parents and their ability to recombine alleles. This depends on dominance effects, complementarity of the alleles in heterozygosis and intergenic interactions, which results in heterosis or hybrid vigor gain. This biological phenomenon can be defined as an increase in a certain character in the progeny when compared to their parents (Falconer and Mackay, 1996).

Numerous breeding studies have been conducted using quantitative genetics to infer variance components, genetic parameters and heterosis in progenies of maize half-sibs (Hallauer and Miranda Filho, 1995; Heinz et al., 2012). However, biometric emphasis on grain yield components, micronutrients, bioactive compounds and amino acids are uncommon. We estimated the most relevant heterosis effects, variance components and genetic parameters, and used a multivariate approach to define narrow sense heritability profiles for yield and nutritional components in half-sib maize progenies.

\section{MATERIAL AND METHODS}

This experiment was performed during the 2015/2016 growing season, at the Plant Genomics and Breeding Center of the Federal University of Pelotas. The genotypes used were grown in the Agricultural Research Station situated at Capão do Leão - RS, Brazil, with $31^{\circ} 47^{\prime} 58^{\prime \prime}$ S latitude and 52 $31^{\prime} 02^{\prime \prime}$ W longitude, with altitude of 13 meters. According to Köppen, the climate is described as Cfa subtropical and the soil is 
characterized as paleudal. The used experimental design was random blocks, with a male parent (hybrid tester), five inbred lines $\left(\mathrm{S}_{5}\right)$ as maternal parents, and their progenies (Top Cross Hybrids), totaling 11 maize genotypes arranged in six replicates (Table 1).

Table 1: Organization of the Top Cross crossing system and the maize genotypes used.

\begin{tabular}{|c|c|c|}
\hline \multicolumn{3}{|c|}{ Genotypes } \\
\hline Tester & Inbred lines $\left(\mathrm{S}_{5}\right)$ & Hybrid (Top Cross) \\
\hline & $\mathrm{L}_{1}(256)$ & HIB I ( $\mathrm{L}_{1}$ x HD) \\
\hline CD 308 & $\mathrm{~L}_{2}(258)$ & HIB II ( $L_{2} \times$ HD) \\
\hline Double cross hybrid (DH) & $\mathrm{L}_{3}(389)$ & HIB III ( $\left.\mathrm{L}_{3} \times \mathrm{HD}\right)$ \\
\hline Broad genetic basis & $\mathrm{L}_{4}(262)$ & HIB IV (L $\left.\mathrm{L}_{4} \times \mathrm{HD}\right)$ \\
\hline & $\mathrm{L}_{5}(225)$ & HIB V ( $\mathrm{L}_{5}$ x HD) \\
\hline
\end{tabular}

Seeding was manually realized in the first half of December 2015, with a population density of 80000 plants per hectare. The fertilizing was performed with350 kg ha ${ }^{-1}$ of NPK as the base fertilizer in the formulation 10-20-20, applied at V4 growing stage, at a rate of $112 \mathrm{~kg} \mathrm{ha}^{-1}$ of amine nitrogen. Weed and pest insect control were carried out according to the needs of the crop, aiming to minimize biotic effects. The experimental unit was composed of two sowing rows, five meters long, and spaced with $0.5 \mathrm{~m}$ between rows. Plants were harvested at the second fortnight of April, 2016.

The characters were measured by random sampling 10 plants per experimental unit, based on the methods proposed by Carvalho et al. (2016) and Souza et al. (2015), as follows: plant height $(\mathrm{PLH}, \mathrm{cm})$, ear insertion height $(\mathrm{SH}, \mathrm{cm})$, ear diameter $(\mathrm{SD}, \mathrm{mm})$, ear length (SL, cm), number of rows per ear (NR, unit), number of grains per row per ear (GR, unit), ear mass (SM, g), mass of grains per ear (GM, g), cob diameter (CD, mm), cob mass (CM, g), mass of one hundred grains (HM, g), grain length (GL, mm), grain width (GW, $\mathrm{mm})$, grain thickness $(\mathrm{GT}, \mathrm{mm})$ and grain yield $\left(\mathrm{GY}, \mathrm{kg} \mathrm{ha}^{-1}\right)$.

The nutritional characters measured as follows: the seeds were crushed in a Marconi ${ }^{\circledR}$ MA020 Thousand equipped with a $0.053 \mathrm{~mm}$ sieve. The ground sample of each genotype was subdivided into six subsamples of $100 \mathrm{~g}$ (Carvalho et al., 2016). Subsequently, iron $(\mathrm{Fe})$, copper $(\mathrm{Cu})$, zinc $\left(\mathrm{Zn}, \mathrm{mg} \mathrm{kg}^{-1}\right)$, sodium $\left(\mathrm{Na}, \mathrm{mg} \mathrm{kg}^{-1}\right)$ and manganese (Mn, mg kg${ }^{-1}$ ) contents were measured as $\mathrm{mg} \mathrm{kg}^{-1}$ in the seeds (Tedesco et al., 1995).

The seed color ( $\mathrm{SC}$, Hue angle), acidity (AC, percentage), $\mathrm{pH}$, soluble solids (SS, Brix), total carotenoids (CA, $\mu \mathrm{g} \mathrm{g}^{-1}$ ) (AOAC, 2005), total phenols (FO, $\mu \mathrm{g} \mathrm{g}^{-1}$ ) (Singleton

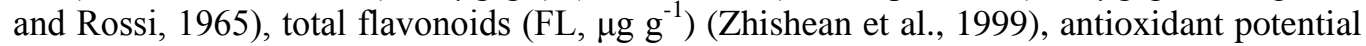
by the DPPH radical (DP, percentage of inhibition) (Brand Williams et al., 1995), and antioxidant potential by the ABTS radical (AB, percent inhibition) (Rufino et al. 2007) were measured. Subsequently, the LC-ESI-qToF-MS metabolite profiling method and mass spectrometry (Table 2) was used to quantify the amino acids contained in the maize seeds, based on the methodology proposed by Vos et al. (2007).

The data were submitted to a normality test (Shapiro Wilk, 1965), followed by deviance analysis $(\mathrm{P} \leq 0.05)$, by the chi-square test $\left(\mathrm{X}^{2}\right)$, in order to identify the significance of the character. Model 1 proposed by Resende (2007) was used to estimate variance components and genetic parameters (REML) for the half-sibling maize progenies and to meet the assumptions of the experiment. Afterwards, the statistical model $\mathrm{y}=\mathrm{Xr}+\mathrm{Za}+$ $\mathrm{Wp}+\mathrm{e}$ was applied, where $y$ is the data vector, $r$ is the effects of repetitions (fixed), $a$ is the individual additive genetics effects (random), $p$ is the progenies effects, and $e$ is the 
residual effects (random). The additive genetic variance (Va), individual phenotypic variance $(\mathrm{Vp})$, environment between progenies variance (Vep), residual variance (Ve), narrow sense heritability $\left(h^{2} a\right)$, narrow sense heritability between the progenies $\left(h^{2} e p\right)$, narrow sense heritability within the progenies $\left(h^{2} d p\right)$, average narrow sense heritability of the progenies $\left(h^{2} \mathrm{~m}\right)$, coefficient of determination of progeny effects $\left(\mathrm{c}^{2}\right)$, progeny accuracy $(\mathrm{Ac})$, genotypic variation of progenies coefficient $(\mathrm{CVg})$, coefficient of residual variation $(\mathrm{CVe})$ and characters overall mean(MG) were calculated.

Table 2: Specifications of the LC-ESI-qToF-MS metabolite profiling method and mass spectrometry used to quantify the maize seeds amino acids.

\begin{tabular}{|c|c|c|c|c|c|c|c|}
\hline Amino acid & Abbreviation & $\begin{array}{l}\text { Retention time } \\
\text { minutes }\end{array}$ & Experimental m/z & Theoretical $\mathrm{m} / \mathrm{z}$ & Error (ppm) & Formula & Search location \\
\hline Alanine & $\mathrm{AL}^{\beta}$ & 1.8600 & 90.0550 & 90.5500 & 0 & $\mathrm{C}_{3} \mathrm{H}_{7} \mathrm{NO}_{2}$ & Metlin $^{*}$ \\
\hline Arginine & $\mathrm{AR}^{\beta}$ & 11.5400 & 454.2340 & 454.2384 & 9 & $\mathrm{C}_{6} \mathrm{H}_{12} \mathrm{~N}_{4} \mathrm{O}_{2}$ & Metlin \\
\hline Asparagine & $\mathrm{AS}^{\beta}$ & 8.0600 & 188.0100 & 188.0101 & 0 & $\mathrm{C}_{17} \mathrm{H}_{33} \mathrm{~N}_{7} \mathrm{O}_{6}$ & Metlin \\
\hline Cysteine & $\mathrm{CI}^{\mathrm{\beta}}$ & 14.7300 & 565.2550 & 565.2551 & 0 & $\mathrm{C}_{24} \mathrm{H}_{36} \mathrm{~N}_{8} \mathrm{O}_{6} \mathrm{~S}$ & Metlin \\
\hline Glutamine & $\mathrm{GL}^{\beta}$ & 1.5300 & 147.5000 & 147.0531 & 3 & $\mathrm{C}_{5} \mathrm{H}_{9} \mathrm{NO}_{4}$ & Mass Bank** \\
\hline Glycine & $\mathrm{GI}^{\beta}$ & 11.5400 & 454.2340 & 454.2384 & 9 & $\mathrm{C}_{17} \mathrm{H}_{33} \mathrm{~N}_{7} \mathrm{O}_{6}$ & Metlin \\
\hline Proline & $\mathrm{PR}^{\beta}$ & 1.9100 & 116.0600 & 115.0633 & 1 & $\mathrm{C}_{5} \mathrm{H}_{9} \mathrm{NO}_{2}$ & Metlin \\
\hline Serine & $\mathrm{SE}^{\beta}$ & 11.5400 & 454.2340 & 454.2384 & 9 & $\mathrm{C}_{17} \mathrm{H}_{33} \mathrm{~N}_{7} \mathrm{O}_{6}$ & Metlin \\
\hline Histidine & $\mathrm{HI}^{\alpha}$ & 14.6800 & 441.2030 & 441.2027 & 0 & $\mathrm{C}_{17} \mathrm{H}_{25} \mathrm{~N}_{7} \mathrm{O}_{4} \mathrm{~S}$ & Metlin \\
\hline Threonine & $\mathrm{TE}^{\beta}$ & 12.4500 & 468.2490 & 468.2463 & 7 & $\mathrm{C}_{12} \mathrm{H}_{33} \mathrm{~N}_{5} \mathrm{O}_{7}$ & Metlin \\
\hline Tryptophan & $\mathrm{TR}^{\alpha}$ & 14.8000 & 595.2760 & 595.2711 & 0 & $\mathrm{C}_{25} \mathrm{H}_{36} \mathrm{~N}_{10} \mathrm{O}_{6}$ & Metlin \\
\hline Methionine & $\mathrm{MT}^{\alpha}$ & 14.6800 & 441.2030 & 441.2027 & 0 & $\mathrm{C}_{17} \mathrm{H}_{25} \mathrm{~N}_{7} \mathrm{O}_{4} \mathrm{~S}$ & Metlin \\
\hline Phenylalanine & $\mathrm{PE}^{\alpha}$ & 6.4100 & 166.0860 & 166.0863 & 1 & $\mathrm{C}_{9} \mathrm{H}_{11} \mathrm{NO}_{2}$ & Metlin \\
\hline
\end{tabular}

The means were used to determine the percentage of heterosis (Ramalho et al., 2012). Later, the $h^{2} a, h^{2} e p, h^{2} d p$ and $h^{2} m$ were used to perform the genetic dissimilarity analysis of the characters using the mean Euclidean Distance and Unweighted Pair Grouping Method with Arithmetic Mean (UPGMA) clustering method. Singh's method was used to determine the relative contribution of narrow sense heritabilities and character differentiation (Singh, 1981). The analyses were carried out using the software Selegen (Resende, 2016) and Genes (Cruz, 2013).

\section{RESULTS AND DISCUSSION}

Deviance analysis was performed for the 42 characters; it revealed significance for 34 characters at $\mathrm{P} \leq 0.05$ by the chi-square test. However, the ear insertion height, cob diameter, grains length, total phenols, cysteine, glutamine, histidine and phenylalanine were not significant, so the estimates of variance components and genetic parameters did not obtain the necessary consistency for these characters.

The phenotypic ratios for plant height of maize half-sibling progenies were $9.4 \%$ due to additive genetic effects. However, the differentiations expressed between progenies represented $26.7 \%$ of Va (Table 3). The narrow sense heritability between ( $\left.h^{2} \mathrm{ep}: 0.15\right)$ and within ( $\mathrm{h}^{2} \mathrm{dp}$ : 0.11) progenies were low; other reports of half-sibling maize in breeds indicated low narrow sense heritability(h2:0.18) in Minas Gerais state (Faluba et al., 2010). This character is highly influenced by the environment; $70.5 \%$ of the ratio between the coefficients of genotypic and residual variation were due to environmental effects. 
Table 3: Estimates of variance components and genetic parameters (individual REML) for half-sibling maize progenies.

\begin{tabular}{|c|c|c|c|c|c|c|c|c|c|c|c|c|c|c|}
\hline Characters & $\mathrm{D}\left(\mathrm{x}^{2} 5 \%\right)$ & $\mathrm{Va}^{+}$ & $\mathrm{Vp}$ & Vep & Ve & $\mathrm{h}^{2} \mathrm{a}$ & $\mathrm{h}^{2} \mathrm{ep}$ & $\mathrm{h}^{2} \mathrm{dp}$ & $\mathrm{h}^{2} \mathrm{~m}$ & $c^{2}$ & $\mathrm{Ac}$ & $\mathrm{CVg}$ & $\mathrm{CVe}$ & MG \\
\hline PLH & * & 110.07 & 1168.01 & 411.01 & 646.92 & 0.09 & 0.15 & 0.11 & 0.08 & 0.35 & 0.28 & 2.42 & 11.81 & 216.54 \\
\hline $\mathrm{SH}$ & ns & 45.48 & 447.61 & 49.99 & 352.14 & 0.10 & 0.11 & 0.09 & 0.11 & 0.11 & 0.34 & 2.99 & 11.86 & 112.71 \\
\hline SD & $*$ & 5.48 & 58.96 & 21.59 & 31.89 & 0.09 & 0.15 & 0.11 & 0.08 & 0.37 & 0.27 & 2.74 & 13.56 & 42.73 \\
\hline SL & $*$ & 1.20 & 12.28 & 3.78 & 7.23 & 0.10 & 0.14 & 0.11 & 0.08 & 0.31 & 0.29 & 4.33 & 20.17 & 12.65 \\
\hline NR & * & 0.847 & 8.86 & 2.97 & 5.04 & 0.10 & 0.14 & 0.11 & 0.08 & 0.34 & 0.28 & 3.42 & 16.41 & 13.44 \\
\hline GR & * & 7.91 & 86.44 & 33.06 & 45.47 & 0.09 & 0.15 & 0.12 & 0.07 & 0.38 & 0.27 & 6.14 & 30.91 & 22.92 \\
\hline SM & * & 392.76 & 5543.21 & 3190.86 & 1959.58 & 0.07 & 0.17 & 0.13 & 0.05 & 0.58 & 0.22 & 7.95 & 50.35 & 124.71 \\
\hline GM & * & 389.18 & 4438.71 & 1875.07 & 2174.45 & 0.09 & 0.15 & 0.12 & 0.07 & 0.42 & 0.26 & 9.29 & 48.91 & 106.18 \\
\hline CD & ns & 1.32 & 12.77 & 1.61 & 9.84 & 0.10 & 0.12 & 0.09 & 0.11 & 0.13 & 0.33 & 2.31 & 9.20 & 24.83 \\
\hline $\mathrm{CM}$ & $*$ & 16.32 & 165.62 & 49.37 & 99.92 & 0.10 & 0.14 & 0.11 & 0.09 & 0.30 & 0.29 & 8.74 & 40.28 & 23.12 \\
\hline HM & $*$ & 3.97 & 39.73 & 11.05 & 24.71 & 0.10 & 0.14 & 0.11 & 0.09 & 0.28 & 0.30 & 3.27 & 14.76 & 30.50 \\
\hline GL & ns & 0.30 & 2.89 & 0.45 & 2.13 & 0.10 & 0.12 & 0.10 & 0.11 & 0.16 & 0.33 & 2.35 & 9.53 & 11.68 \\
\hline GW & * & 0.05 & 0.46 & 0.11 & 0.31 & 0.10 & 0.13 & 0.10 & 0.10 & 0.24 & 0.31 & 1.31 & 5.70 & 8.32 \\
\hline GT & $*$ & 0.01 & 0.13 & 0.02 & 0.09 & 0.10 & 0.12 & 0.10 & 0.11 & 0.16 & 0.33 & 1.27 & 5.20 & 4.54 \\
\hline GY & $*$ & 1914697.87 & 21818829.39 & 9200378.65 & 10703752.86 & 0.09 & 0.15 & 0.12 & 0.07 & 0.42 & 0.26 & 9.32 & 49.01 & 7425.65 \\
\hline $\mathrm{Fe}$ & $*$ & 2.25 & 21.92 & 5.05 & 14.61 & 0.10 & 0.13 & 0.10 & 0.10 & 0.23 & 0.31 & 3.05 & 13.16 & 24.61 \\
\hline $\mathrm{Cu}$ & $*$ & 0.34 & 3.55 & 1.15 & 2.06 & 0.10 & 0.14 & 0.11 & 0.08 & 0.32 & 0.29 & 8.97 & 42.53 & 3.26 \\
\hline $\mathrm{Zn}$ & $*$ & 4.21 & 56.24 & 30.43 & 21.60 & 0.07 & 0.16 & 0.13 & 0.05 & 0.54 & 0.23 & 3.18 & 19.28 & 32.25 \\
\hline $\mathrm{Na}$ & * & 61.29 & 617.47 & 178.10 & 378.08 & 0.10 & 0.14 & 0.11 & 0.09 & 0.29 & 0.30 & 2.18 & 9.96 & 179.39 \\
\hline $\mathrm{Mn}$ & * & 2.88 & 51.39 & 35.45 & 13.06 & 0.06 & 0.18 & 0.14 & 0.03 & 0.69 & 0.19 & 5.36 & 40.21 & 15.83 \\
\hline
\end{tabular}

${ }^{+} \mathrm{D}$ : Deviance based on $\mathrm{X}^{2}$ at $5 \%$ probability; Va: additive genetic variance; Vp: phenotypic individual variance; Vep: environmental variance between the progenies; Ve: residual variance; $h^{2} a$ : Narrow sense heritability of additive effects; $h^{2}$ ep: Narrow sense heritability between the progenies; $h^{2} d p$ : Narrow sense heritability within the progenies; $h^{2} m$ : Narrow sense heritability between means of progenies; $\mathrm{c}^{2}$ : Coefficient of determination of progeny effects; Ac: Accuracy of the progenies; $\mathrm{CVg}$ : Coefficient of genotypic variation between the progenies; CVe: Coefficient of residual variation; MG: General mean of the character.

PLH: Plant Height; SH: ear insertion height; SD: ear diameter; SL: ear length; NR: number of rows of grains per ear; GR: number of grains per row per ear; SM: ear mass; GM: mass of grains per ear; CD: cob diameter; CM: cob mass; HM: one hundred grain mass; GL: grain length; GW: grain width; GT: grain thickness; GY: grain yield; Fe: iron content; $\mathrm{Cu}$ : copper content; $\mathrm{Zn}$ : zinc content; Na: sodium content; $\mathrm{Mn}$ : manganese content in the grain

Regarding maize ear characters, higher contributions of additive genetic fractions to the phenotypic expression were observed for stalk mass (9.8\%), ear length $(9.7 \%)$ and number of grain rows per ear $(9.5 \%)$. However, the additive genetic features contributed $33.0 \%$ for cob mass and $31.7 \%$ for ear length and phenotypically differentiated progenies. The additive effects of narrow sense heritability revealed similar magnitudes $\left(\mathrm{h}^{2} \mathrm{a}: 0.10\right)$ for ear length, number of grain rows per ear and cob mass. On the other hand, narrow sense heritability between the progenies was greater for ear diameter ( $\left.h^{2} e p: 0.15\right)$ and mass $\left(h^{2} e p:\right.$ 0.17). Other research, studying 27 maize genotypes grown in five environments, at the southern region of Brazil, showed broad sense heritabilities of $0.70,0.65,0.62$ and 0.70 for ear length, ear mass, grains mass per ear and stalk mass, respectively (Nardino et al., 2016).

The coefficient of determination for progeny effects was higher for ear mass $\left(\mathrm{c}^{2}\right.$ : 0.58). The low accuracy (Ac: 0.22 ) obtained indicated a large environmental effect on this character. Accuracy was divided into high $(0.70<\mathrm{Ac})$, moderate $(0.50<\mathrm{Ac}<0.65)$, and low $(0.10<A c<0.40)$, according to Resende and Duarte (2007). The ear and cob mass evidenced the highest coefficients of genotypic variation for these characters, which demonstrated variability for the progenies, but with marked residual effects.

Regarding to the dimensional properties of maize grains, width was determined by $10.8 \%$ of additive genetic effects, while one hundred grains mass $(9.9 \%)$ and grain thickness $(7.6 \%)$ had slightly lower values. However, between the progenies the grain thickness was $50.0 \%$ of the additive genetic fraction, being greater than mass of one hundred grains $(35.9 \%)$ and grain width $(45.4 \%)$. The narrow sense heritability for additive effects $\left(h^{2} a\right)$ and within the progenies $\left(h^{2} d p\right)$ was similar $(0.10)$ for mass of one hundred 
grains, grain width and thickness. However, the highest narrow sense heritability between the progenies ( $h^{2}$ ep: 0.14) was observed for mass of one hundred grains. Other reports on intervarietal crosses in maize show that narrow sense heritability $\left(\mathrm{h}^{2}\right)$ is low for the mass of one hundred grains (0.06), grain length (0.11) and width (0.19) (Carvalho et al., 2016).

The coefficient of determination for the progeny effects was higher for mass of one hundred grains ( $\left.\mathrm{c}^{2}: 0.28\right)$; among the grain size properties, this was the most influenced trait by environmental effects, although the accuracy was low (Ac: 0.30 ) for these characters. The ratio of the coefficient of genotypic variation to the residual variation indicated a contribution of $24.4 \%$ of the genetic fraction in the total variation of grain thickness.

Grain yield was the result of $8.7 \%$ additive gene effects. Among the progenies, these (Va) were even greater, reaching $20.8 \%$ of the phenotypic variation. The narrow sense heritability between $\left(h^{2} \mathrm{ep}: 0.15\right)$ and within $\left(\mathrm{h}^{2} \mathrm{dp}: 0.12\right)$ progenies was low. Consequently, understanding the additive genetic variation becomes essential to the breeder even if it does not reveal which gene actions are involved. However, it can be determined by the average effects of several alleles together and will include heritable effects, genotypic differentiations and selection responses (Falconer and Mackay, 1996). Reports on halfsibling maize lines indicate narrow sense heritability of $h^{2}: 0.49$ for grain yield. However, the magnitude of this parameter could be influenced by the number of plants measured (Palomino et al., 2000).

The coefficient of determination for progeny effects was high $\left(c^{2}=0.42\right)$, but with low accuracy $(A c=0.26)$. Reports regarding single cross hybrids cultivated in five environments indicated coefficient of determination estimates $\left(c^{2}=0.66\right)$ and moderate accuracies for grain yield. The magnitude of these parameters could be due to the nature of the genotype, the number of observations and the variations imposed by the environment (Souza et al., 2015).

Iron, copper and sodium micronutrients revealed the highest contributions of additive genetic variance to phenotypic expression, indicating $10.2 \%, 9.5 \%$ and $9.9 \%$, respectively. Between the progenies, larger effects were obtained for iron content, being $44.5 \%$ of the phenotypic variation resultant from the additive gene fraction. Narrow sense heritability was similar ( $\left.\mathrm{h}^{2} \mathrm{a}: 0.10\right)$ for iron, copper and sodium content. In contrast, narrow sense heritability between and within progenies was higher for zinc $\left(\mathrm{h}^{2} \mathrm{ep}: 0.16 ; \mathrm{H}^{2} \mathrm{dp}: 0.13\right)$ and manganese ( $\left.h^{2} \mathrm{ep}: 0.18 ; \mathrm{h}^{2} \mathrm{dp}: 0.14\right)$. The coefficient of determination of progeny effects $\left(c^{2}: 0.69\right)$ was high for manganese. However, for all micronutrients, low accuracy was obtained; this can be attributed to environmental effects. Iron content revealed that $23.1 \%$ of total variance was originated from genetic causes. Among intervarietal maize genotypes, the highest contribution of additive genetic variance and narrow sense heritability ( $\mathrm{h}^{2}: 0.34$ ) was obtained for sodium content, since for micronutrients, the low magnitudes of genetic parameters were due to the large environmental effects on the dynamics of these characters and non-additive deviations (Carvalho et al., 2016).

Bioactive compounds such as total flavonoids, soluble solids and seed color (Table 4) displayed $10.0 \%, 10.0 \%$ and $10.4 \%$, respectively, of theVp expression explained by Va. Between progenies, character trends were maintained and proportions increased up to $38.4 \%, 36.6 \%$ and $50.0 \%$ of the contribution of theVa expression to the phenotype. Low genetic contributions were found for the acidity and $\mathrm{pH}$ of the seeds in the general scope, and between half-sibling progenies. The differences revealed for these characters were mostly caused by non-additive deviations and environmental effects. In maize, the total 
flavonoids are abundant and essential for defense against stresses caused by abnormal temperature, water deficits, high salinity, ultraviolet radiation, diseases and insect pests (Wen et al., 2014).

Table 4: Estimates of variance components and genetics parameters (individual REML) for the half-sibling maize progenies.

\begin{tabular}{|c|c|c|c|c|c|c|c|c|c|c|c|c|c|c|}
\hline Character & $\mathrm{D}\left(\mathrm{x}^{2} 5 \%\right)$ & $\mathrm{Va}^{+}$ & $V p$ & Vep & $\mathrm{Ve}$ & $\mathrm{h}^{2} \mathrm{a}$ & $\mathrm{h}^{2} \mathrm{ep}$ & $h^{2} d p$ & $\mathrm{~h}^{2} \mathrm{~m}$ & $\mathrm{c}^{2}$ & $\mathrm{Ac}$ & $\mathrm{CVg}$ & Cve & MG \\
\hline $\mathrm{FO}^{++}$ & $\mathrm{ns}$ & 6488.84 & 62318.12 & 9287.00 & 46542.27 & 0.10 & 0.12 & 0.09 & 0.11 & 0.15 & 0.33 & 4.06 & 16.38 & 992.53 \\
\hline FL & $*$ & 44893.77 & 444533.24 & 116721.41 & 282918.06 & 0.10 & 0.14 & 0.11 & 0.09 & 0.26 & 0.30 & 5.57 & 24.78 & 1902.59 \\
\hline CA & * & 111.61 & 1334.37 & 616.64 & 606.13 & 0.08 & 0.16 & 0.12 & 0.06 & 0.46 & 0.25 & 4.72 & 25.98 & 112.01 \\
\hline DP & * & 13.61 & 177.46 & 93.32 & 70.53 & 0.08 & 0.16 & 0.13 & 0.05 & 0.53 & 0.23 & 6.11 & 36.31 & 30.20 \\
\hline $\mathrm{AB}$ & * & 5.31 & 74.39 & 42.51 & 26.57 & 0.07 & 0.17 & 0.13 & 0.05 & 0.57 & 0.22 & 2.07 & 13.03 & 55.73 \\
\hline SS & * & 0.37 & 3.70 & 1.01 & 2.32 & 0.10 & 0.14 & 0.11 & 0.09 & 0.27 & 0.30 & 8.38 & 37.68 & 3.64 \\
\hline AC & * & 0.00 & 0.02 & 0.01 & 0.01 & 0.10 & 0.14 & 0.11 & 0.09 & 0.27 & 0.30 & 7.43 & 33.34 & 0.32 \\
\hline $\mathrm{pH}$ & * & 0.00 & 0.05 & 0.02 & 0.03 & 0.09 & 0.15 & 0.12 & 0.07 & 0.40 & 0.27 & 0.53 & 2.72 & 6.49 \\
\hline $\mathrm{SC}$ & $*$ & 0.07 & 0.69 & 0.14 & 0.48 & 0.10 & 0.13 & 0.10 & 0.10 & 0.20 & 0.32 & 0.14 & 0.59 & 95.52 \\
\hline $\mathrm{AL}$ & * & 218015.35 & 2200276.92 & 640192.97 & 1342068.60 & 0.10 & 0.14 & 0.11 & 0.09 & 0.29 & 0.30 & 6.29 & 28.78 & 3712.84 \\
\hline $\mathrm{AR}$ & $*$ & 5233121.83 & 60037972.78 & 25674033.92 & 29130817.02 & 0.09 & 0.15 & 0.12 & 0.07 & 0.43 & 0.26 & 9.85 & 52.15 & 11615.43 \\
\hline AS & $*$ & 259676.77 & 2614672.92 & 752330.56 & 1602665.59 & 0.10 & 0.14 & 0.11 & 0.09 & 0.29 & 0.30 & 8.12 & 37.07 & 3136.40 \\
\hline CI & ns & 32130.48 & 832592.43 & 10733.77 & 789728.19 & 0.04 & 0.04 & 0.03 & 0.05 & 0.01 & 0.23 & 1.01 & 5.97 & 8892.94 \\
\hline GU & ns & 102468.54 & 1012833.92 & 109493.00 & 800872.38 & 0.10 & 0.11 & 0.09 & 0.11 & 0.11 & 0.34 & 5.28 & 20.93 & 3029.52 \\
\hline GI & $*$ & 912504.89 & 15142032.79 & 9982214.80 & 4247313.10 & 0.06 & 0.18 & 0.14 & 0.04 & 0.66 & 0.19 & 8.69 & 62.05 & 5495.02 \\
\hline PR & $*$ & 7083504.20 & 115622119.00 & 82803986.70 & 32456965.78 & 0.06 & 0.18 & 0.14 & 0.04 & 0.68 & 0.19 & 5.43 & 39.89 & 24487.44 \\
\hline SE & $*$ & 74798.25 & 1029818.92 & 577482.82 & 377537.86 & 0.07 & 0.17 & 0.13 & 0.05 & 0.56 & 0.22 & 3.47 & 21.56 & 3940.63 \\
\hline $\mathrm{HI}$ & ns & 4286022.58 & 42472496.11 & 4508988.22 & 33677485.31 & 0.10 & 0.11 & 0.09 & 0.11 & 0.11 & 0.34 & 5.45 & 21.58 & 18996.29 \\
\hline TE & $*$ & 1499322.74 & 25656358.33 & 17262293.34 & 6894742.24 & 0.06 & 0.18 & 0.14 & 0.04 & 0.67 & 0.19 & 5.57 & 40.62 & 10992.42 \\
\hline TR & * & 19349.95 & 226458.99 & 100696.10 & 106412.93 & 0.09 & 0.15 & 0.12 & 0.06 & 0.44 & 0.25 & 1.84 & 9.93 & 3782.83 \\
\hline MT & $*$ & 84415.78 & 821344.13 & 189121.84 & 547806.51 & 0.10 & 0.13 & 0.10 & 0.10 & 0.23 & 0.31 & 1.11 & 4.80 & 13065.54 \\
\hline PE & ns & 25999.11 & 6121892.81 & 6663.53 & 6089230.17 & 0.00 & 0.00 & 0.00 & 0.01 & 0.00 & 0.08 & 0.41 & 7.19 & 19870.72 \\
\hline
\end{tabular}

${ }^{+} \mathrm{D}$ : Deviance per $\mathrm{X}^{2}$ a $5 \%$ of probability; Va: additive genetic variance; Vp: phenotypic individual variance; Vep: environmental variance between the progenies; Ve: residual variance; $h^{2} a$ : Narrow sense heritability of additive effects; $h^{2} e p$ : Narrow sense heritability, between the progenies; $h^{2} d p$ : Narrow sense heritability within the progenies; $h^{2} m$ : Narrow sense heritability between the means of progenies; $\mathrm{c}^{2}$ : Coefficient of determination of progenies effects; Ac: Accuracy of the progenies; CVg: Coefficient of genotypic variation between the progenies; CVe: Coefficient of residual variation; MG: General mean of the character.

${ }^{++}$FO: phenols; FL: flavonoids; CA: carotenoids; DP: DPPH antioxidant radical; AB: ABTS antioxidant radical; SS: soluble solids; AC: acid; $\mathrm{pH}$ : hydrogen ionic potential; SC: seed color; AL: alanine; AR: arginine; AS: asparagine; CI: cysteine; GU: glutamine; GI: glycine; PR: proline; SE: serine; HI: histidine; TE: threonine; TR: tryptophan; MT: methionine; PE: phenylalanine.

The narrow sense heritability was similar ( $\left.h^{2}: 0.10\right)$ for total flavonoids, soluble solids and seed color. Differential behavior was expressed by the narrow sense heritability between and within the progenies, with higher magnitudes for total carotenoids ( $\mathrm{h}^{2} \mathrm{ep}: 0.16$; $\left.\mathrm{h}^{2} \mathrm{dp}: 0.12\right)$, antioxidant potential by the DPPH radical ( $\left.\mathrm{h}^{2} \mathrm{ep}: 0.16 ; \mathrm{h}^{2} \mathrm{dp}: 0.13\right)$ and ABTS radical ( $\left.h^{2} e p: 0.17 ; h^{2} d p: 0.13\right)$. Reports have defined that the main carotenoids in maize are lutein, zeaxanthin, and $\beta$-carotene, which are highly dependent on inbred lines, environmental effects and growing season (Azmach et al., 2013). In progenies of halfsibling maize, narrow sense heritability was obtained $\left(h^{2}: 0.19\right)$ for total carotenoids (Halilu et al., 2016). With genitor-progeny regression in maize, narrow sense heritability was obtained for soluble solids $\left(h^{2}: 0.25\right)$, total flavonoids $\left(h^{2}: 0.08\right)$, total carotenoids $\left(h^{2}: 0.48\right)$, antioxidant potential for DPPH radical and ABTS radical $\left(h^{2}: 0.26\right.$ and $\left.h^{2}: 0.07\right)$, respectively (Carvalho et al., 2016). The narrow sense heritability of the progeny means $\left(\mathrm{h}^{2} \mathrm{~m}: 0.10\right)$ is pronounced only for seed color, because it is a character with the greatest contribution of additive genetic fractions to the phenotype and to the indirect effects of the total carotenoids. Pigmentation by carotenoids results in differences in color of maize seeds (Bóremand Rios, 2011).

The coefficient of determination of progeny effects was higher for the antioxidant potential by the DPPH radical $\left(\mathrm{c}^{2}: 0.53\right)$ and ABTS radical $\left(\mathrm{c}^{2}: 0.57\right)$. This is due to the 
indirect estimation method for these traits, and can be overcome by increasing the number of observations in the experimental conditions; in general, low accuracies were revealed for the bioactive compounds. When comparing proportionality between the coefficients of variation, it was observed that the total flavonoids, soluble solids, and the seed color accounted for 22.4, 22.2 and $23.7 \%$, respectively, of the contribution of the genetic fraction to the total variation of the bioactive compounds.

In this study, using half-sibling maize progenies, we identified 13 amino acids, including alanine, arginine, asparagine, cysteine, glutamine, glycine, proline, serine, histidine, threonine, tryptophan, methionine and phenylalanine. Studies using 15 single cross maize hybrids grown in four environments of Rio Grande do Sul obtained 6.5\% of crude protein in the grains (Carvalho et al., 2016).

Among the amino acids identified, alanine, asparagine, tryptophan and methionine contributed with $9.9,9.9,8.5$ and $10.2 \%$ of the phenotypic expression by additive genetic variance. Among the progenies, character trends were maintained and proportions were increased, where alanine, asparagine and methionine were determined by 34.0, 34.5 and $44.6 \%$ of the additive gene fraction, respectively. The narrow sense heritability of additive effects was low ( $\left.\mathrm{h}^{2} \mathrm{a}: 0.10\right)$ for alanine, asparagine and methionine. For narrow sense heritability within and between progenies, prominent results were expressed for arginine and tryptophan $\left(h^{2} \mathrm{ep}: 0.15 ; \mathrm{h}^{2} \mathrm{dp}: 0.12\right)$, glycine, proline and threonine $\left(\mathrm{h}^{2} \mathrm{ep}: 0.18 ; \mathrm{h}^{2} \mathrm{dp}\right.$ : 0.14 ), and serine ( ${ }^{2} \mathrm{ep}: 0.17 ; \mathrm{h}^{2} \mathrm{dp}: 0.13$ ). The highest narrow sense heritability of progeny means $\left(h^{2} \mathrm{~m}: 0.10\right)$ was evidenced for methionine. Maize breeding may increase the total proportion of amino acids by increasing the protein fraction of the grains. However, lysine and tryptophan can accumulate at lower levels than other amino acids, while higher phenylalanine may lead to oil content increases (Wen et al., 2016).

The coefficient of determination of progeny effects was high for glycine $\left(\mathrm{c}^{2}: 0.60\right)$, proline $\left(\mathrm{c}^{2}: 0.68\right)$, serine $\left(\mathrm{c}^{2}: 0.56\right)$ and threonine $\left(\mathrm{c}^{2}: 0.67\right)$, these being results of genetic differentiation, environmental effects and the peculiarities involved in the measurement of these amino acids. However, when analyzing the ratios of coefficients of variation, a contribution of $21.8,21.9$, and $23.1 \%$ of the genetic fraction to the total variation was found for the amino acids alanine, asparagine and methionine, respectively. Heterosis was estimated for the 42 characters measured in half-sibling maize progenies (Table 5), where the estimation of this parameter was obtained for each inbred line $\mathrm{S}_{5}$ (L1: 256, L2: 258, L3: 389, L4: 262 and L5: 225) cross-linked with a broad genetic based tester (HD: CD308) pollen donor.

Regardless the use of an inbreeding line $\mathrm{S}_{5}$, the crosses showed heterosis for ear insertion height, number of grain rows per ear, stalk diameter, zinc content, total carotenoids, soluble solids and $\mathrm{pH}$, with a mean increase of 20.8 26.0, 8.6, 31.1, 36.3, 74.9 and $6.9 \%$ in the half sibling progenies, respectively. Using the inbred line $\mathrm{L}_{2}: 258$ as the female parent, it was possible to specifically increase sodium content, total flavonoids and threonine amino acid by $6.1,15.4$ and $84.1 \%$, respectively. Therefore, efficient choice of the line to be used in the cross makes it possible to increase a given micronutrient, bioactive compound or amino acid in the progeny by means of heterosis. Heterosis is dependent on the genetic distance, allelic frequency and hybrid combination between certain parents; these conformations are complementary and provide evidence of non-additive effects from dominance and over dominance (Paterniani et al., 2008). 
Table 5: Estimates of heterosis (\%) obtained in Top Crosses between inbred lines $\mathrm{S}_{5}\left(\mathrm{~L}_{1}: 256, \mathrm{~L}_{2}: 258, \mathrm{~L}_{3}: 389\right.$, $\left.\mathrm{L}_{4}: 262, \mathrm{~L}_{5}: 225\right)$ and a tester (HD: CD 308) with broad genetic basis.

\begin{tabular}{|c|c|c|c|c|c|c|c|c|c|c|c|}
\hline \multicolumn{12}{|c|}{ Heterosis $\left(\mathrm{H}^{+}\right)$} \\
\hline \multirow{2}{*}{ Character } & $\mathrm{L}_{1} \mathrm{xHD}$ & $\mathrm{L}_{2} \mathrm{xHD}$ & $\mathrm{L}_{3} \mathrm{xHD}$ & $\mathrm{L}_{4} \mathrm{xHD}$ & $\mathrm{L}_{5} \mathrm{xHD}$ & & $\mathrm{L}_{1} \mathrm{xHD}$ & $\mathrm{L}_{2} \mathrm{xHD}$ & $\mathrm{L}_{3} \mathrm{xHD}$ & $\mathrm{L}_{4} \mathrm{xHD}$ & $\mathrm{L}_{5} \mathrm{xHD}$ \\
\hline & HIB (I) & HIB (II) & HIB (III) & HIB (IV) & HIB (V) & & HIB (I) & HIB (II) & HIB (III) & HIB (IV) & $\mathrm{HIB}(\mathrm{V})$ \\
\hline $\mathrm{PLH}^{++}$ & -6.88 & 16.65 & -0.24 & 26.57 & 20.36 & FL & -20.18 & 15.40 & -59.71 & -15.84 & -15.88 \\
\hline SH & 3.09 & 18.53 & 7.07 & 50.46 & 24.78 & $\mathrm{CA}$ & 51.97 & 8.65 & 35.98 & 60.55 & 24.38 \\
\hline SD & -4.81 & 16.46 & 12.76 & 7.83 & 10.20 & DP & 113.27 & 82.13 & -15.16 & 91.97 & 182.51 \\
\hline SL & -8.74 & 19.25 & -2.15 & -3.04 & 1.27 & $\mathrm{AB}$ & 40.06 & 21.85 & 8.37 & 36.37 & -15.04 \\
\hline NR & 13.93 & 5.29 & 30.23 & 29.90 & 50.54 & SS & 33.33 & 200.00 & 100.00 & 7.69 & 33.33 \\
\hline GR & -13.45 & -2.35 & 24.84 & 23.08 & 5.76 & AC & -52.99 & -46.01 & -36.15 & -47.49 & -59.35 \\
\hline SM & -26.17 & 54.81 & 10.86 & -6.39 & 12.70 & $\mathrm{pH}$ & 6.32 & 6.06 & 6.24 & 7.11 & 8.78 \\
\hline GM & -24.40 & 77.30 & 18.89 & 0.69 & 24.68 & $\mathrm{HU}$ & -0.27 & 2.06 & -0.39 & 1.51 & 0.68 \\
\hline $\mathrm{CD}$ & 3.59 & 1.02 & 10.49 & 13.26 & 14.50 & $\mathrm{AL}$ & -48.05 & -2.54 & -24.73 & -29.66 & -48.15 \\
\hline $\mathrm{CM}$ & -35.31 & 46.51 & -21.16 & 25.55 & 57.67 & $\mathrm{AR}$ & -77.27 & -32.70 & -25.91 & -79.76 & -60.08 \\
\hline HM & -10.56 & 5.18 & 2.33 & 1.24 & 2.22 & AS & -44.91 & 5.24 & -30.90 & -41.48 & -35.50 \\
\hline GL & 5.46 & 8.54 & 18.35 & 14.16 & -5.71 & $\mathrm{CI}$ & 1.97 & 2.68 & 16.12 & -18.37 & -3.72 \\
\hline GW & -5.15 & -0.96 & -3.69 & -0.47 & -8.16 & GL & -8.50 & 33.11 & -11.82 & 6.24 & 9.40 \\
\hline GT & 2.80 & -11.66 & 0.13 & -8.68 & -3.12 & GI & 41.44 & 193.21 & -26.42 & -40.09 & -54.59 \\
\hline GY & -24.40 & 77.30 & 18.89 & 1.22 & 24.68 & PR & 20.20 & 10.62 & -25.54 & 13.95 & 91.44 \\
\hline $\mathrm{Fe}$ & 2.57 & 22.18 & 36.21 & -12.12 & -9.34 & SE & -46.17 & 26.01 & 18.88 & -17.86 & -6.55 \\
\hline $\mathrm{Cu}$ & 160.78 & -73.37 & 31.35 & -6.90 & -57.40 & $\mathrm{HI}$ & -3.25 & -38.57 & -44.98 & -21.05 & -16.09 \\
\hline $\mathrm{Zn}$ & 55.02 & 32.46 & 30.97 & 30.95 & 6.12 & $\mathrm{TE}$ & -9.81 & 84.07 & -36.96 & -27.87 & -37.58 \\
\hline $\mathrm{Na}$ & -17.17 & 6.15 & -13.64 & -2.58 & -28.16 & TR & 5.63 & -11.77 & -11.42 & -25.21 & -14.96 \\
\hline $\mathrm{Mn}$ & 15.13 & 0.75 & 49.70 & 45.34 & -22.19 & MT & 7.84 & -9.02 & -3.77 & -11.76 & -5.04 \\
\hline FO & 32.14 & -48.43 & 38.67 & -39.74 & 13.27 & PE & 5.04 & 22.34 & 12.14 & -5.63 & 3.42 \\
\hline
\end{tabular}
per ear; GR: number of grains per row per ear; SM: ear mass; GM: mass of grains per ear; CD: cob diameter; CM: cob mass; HM: one hundred grains mass; GL: grain length; GW: grain width; GT: grain thickness; GY: grain yield; Fe: iron content; $\mathrm{Cu}$ : copper content; $\mathrm{Zn}$ : zinc content; Na: sodium content; $\mathrm{Mn}$ : manganese content in the grain. FO: phenols; FL: flavonoids; CA: carotenoids; DP: DPPH antioxidant radical; AB: ABTS antioxidant radical; SS: soluble solids; AC: acidity; pH: hydrogen ionic potential; $\mathrm{SC}$ : seed color; AL: alanine; AR: arginine; AS: asparagine; CI: cysteine; GU: glutamine; GI: glycine; PR: proline; SE: serine; HI: histidine; TE: threonine; TR: tryptophan; MT: methionine; PE: phenylalanine.

In general, it was possible to define that, among all the measured characters, the $\mathrm{L}_{2}: 258$ and $\mathrm{L}_{3}: 389$ lines were the most efficient, where 73.8 and $54.7 \%$ of the measured characters in the progenies were increased by heterosis, respectively. By stratifying the heterosis contributions by groups of characters, it was possible to show that the grain yield had an increase of $77.3 \%$ when using the lineage $\mathrm{L}_{2}: 258$ as the maternal parent. Genetic improvement studies, for intervarietal maize hybrids, obtained a mean heterosis of $37.3 \%$ for grain yield (Bernini et al., 2013).

When it is desired to increase the micronutrients in the progeny through cross breeding gains by heterosis, line $\mathrm{L}_{3}: 389$ can be used as the maternal parent; this resulted in increases of 36.2, 31.3, 30.9 and $49.7 \%$ for iron, copper, zinc and manganese content, respectively. Reports have shown that maize genotypes, biofortified with micronutrients, can be produced by genetic engineering and/or conventional breeding, through recombination of parents and progenies that are more efficient in absorbing, transporting and accumulating higher iron, zinc, copper and manganese contents in the grains. Copper, zinc and manganese can be potentiated by increasing the proportions of the amino acids methionine and cysteine; these micronutrients are necessary for enzymes that fight the actions of reactive oxygen species and can minimize the free radicals; in contrast, iron is part of the enzyme catalase, which reduces the effects of the hydrogen peroxide, a precursor of oxidative stress in plants (Rios et al., 2015).

By examining heterosis effects on the bioactive compounds and amino acids in the half sibling maize progenies, we found that line $\mathrm{L}_{2}: 258$ was the best maternal parent, since 
it gave the largest increase in the nutritional characters. This lineage allowed the heterosis for total flavonoids $(15.4 \%)$, total carotenoids $(8.6 \%)$, antioxidant potential by the DPPH radical $(82.1 \%)$ and ABTS (21.8\%), soluble solids (200.0\%), pH (6.0\%), seed color (2.0\%), asparagine $(5.2 \%)$, cysteine $(2.6 \%)$, glutamine $(33.1 \%)$, glycine (193.2\%), proline $(10.6 \%)$, serine $(26.0 \%)$, threonine $(84.0 \%)$ and phenylalanine $(22.3 \%)$.

Heterosis values for bioactive compound in half-sib progenies were lower than those found for progenies from intervarietal crosses. Parental genotype and allele complementarity in heterozygous loci could explain the amplitude of the results for this parameter (Carvalho et al., 2016). The increases in progenies from heterosis due to the use of the $\mathrm{L}_{2}: 258$ line for the eight amino acids were high. However, it is essential to orientate maize breeding, under these conditions, towards amino acids that are essential for humans and animals (Galili et al., 2016), with emphasis on phenylalanine; the progenies were $22.3 \%$ higher for this amino acid when compared to the parents.

A multivariate approach was applied considering the heritability of the additive effects $\left(h^{2} a\right)$ between the progenies $\left(h^{2} e p\right)$, within the progenies $\left(h^{2} d p\right)$ and the mean progenies $\left(\mathrm{h}^{2} \mathrm{~m}\right)$, for the 42 characters measured in the maize genotypes. The mean Euclidean distance was analyzed, in order to examine the profile of the characters in terms of their inherent tendency; the UPGMA grouping was used to express the distances through a dendrogram (Figure 1), and the mean (0.0553) of the matrix of the distances was evidenced as the criterion of separation for narrow sense heritability profiles.

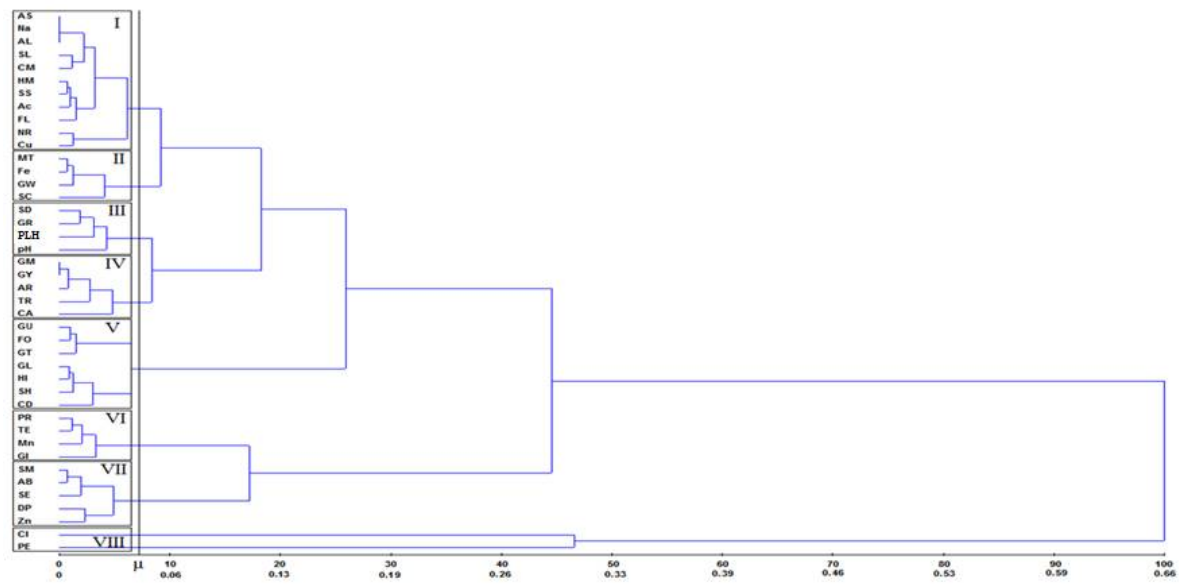

Figure 1: Dendrogram with the genetic dissimilarity obtained through the narrow sense heritability of the additive effects $\left(h^{2} a\right)$, narrow sense heritability between the progenies $\left(h^{2} e p\right)$, narrow sense heritability within the progenies $\left(h^{2} \mathrm{dp}\right)$, and narrow sense heritability of the mean between the progenies $\left(h^{2} \mathrm{~m}\right)$ of the 42 characters measured in half-sibling maize progenies, using the Euclidean distance mean, and UPGMA grouping method. ${ }^{++}$PLH: plant height; SH: ear insertion height; SD: ear diameter; SL: ear length; NR: number of rows of grains per ear; GR: number of grains per row per ear; SM: ear mass; GM: mass of grains per ear; CD: cob diameter; CM: cob mass; HM: one hundred grains mass; GL: grain length; GW: grain width; GT: grain thickness; GY: grain yield; Fe: iron content; $\mathrm{Cu}$ : copper content; $\mathrm{Zn}$ : zinc content; Na: sodium content; Mn: manganese content in the grain. FO: phenols; FL: flavonoids; CA: carotenoids; DP: DPPH antioxidant radical; AB: ABTS antioxidant radical; SS: soluble solids; AC: acidity; $\mathrm{pH}$ : hydrogenation potential; SC: seed color; AL: alanine; AR: arginine; AS: asparagine; CI: cysteine; GU: glutamine; GI: glycine; PR: proline; SE: serine; HI: histidine; TE: threonine; TR: tryptophan; MT: methionine; PE: phenylalanine.Roman numerals represent the narrow sense heritability profiles of the evaluated traits; $\mu$ : mean of the narrow sense heritability distances matrix. 
Profile I ( $\left.h^{2} a: 0.10, h^{2} e p: 0.14, h^{2} d p: 0.11, h^{2} m: 0.09\right)$ clustered ear length, ear mass, mass of one hundred grains, number of grain rows per ear, copper and sodium content, soluble solids, acidity, total flavonoids, asparagine and alanine. Profile II ( $\mathrm{h}^{2} \mathrm{a}: 0.10, \mathrm{~h}^{2} \mathrm{ep}$ : $\left.0.13, \mathrm{~h}^{2} \mathrm{dp}: 0.10, \mathrm{~h}^{2} \mathrm{~m}: 0.10\right)$ clustered grain width, iron content, seed color and methionine. Profile III (ha: 0.09, $\left.h^{2} e p: 0.15, h^{2} d p: 0.12, h^{2} m: 0.08\right)$ associated plant height, ear diameter, number of grains per ear row and ph. Profile IV (ha: 0.09, $\left.h^{2} e p: 0.15, h^{2} d p: 0.12, h^{2} m: 0.07\right)$ clustered grain mass per ear, grain yield, total carotenoids, arginine and tryptophan. Profile V ( $\left.h^{2} \mathrm{a}: 0.10, h^{2} e p: 0.12, h^{2} d p: 0.09, h^{2} m: 0.11\right)$ included the ear insertion height, stalk diameter, grain length and thickness, total phenols, glutamine and histidine. Profile VI ( $\mathrm{h}^{2} \mathrm{a}$ : 0.06, hep: 0.18, $\mathrm{h}^{2} \mathrm{dp}: 0.14, \mathrm{~h}^{2} \mathrm{~m}: 0.04$ ) associated manganese content, glycine, proline and threonine. Profile VII ( $\left.h^{2} \mathrm{a}: 0.07, h^{2} e p: 0.16, h^{2} \mathrm{dp}: 0.13, h^{2} \mathrm{~m}: 0.05\right)$ included ear mass, zinc content, antioxidant potential by DPPH and ABTS radicals, and serine. Profile VIII $\left(\mathrm{h}^{2} \mathrm{a}\right.$ : 0.02, h' $\mathrm{h}^{2} \mathrm{ep:} 0.02, \mathrm{~h}^{2} \mathrm{dp}: 0.02, \mathrm{~h}^{2} \mathrm{~m}: 0.03$ ) clustered cysteine and phenylalanine. Thus, based on Singh's statistical method (1981), the narrow sense heritability of progeny means was the parameter that contributed the most $(34.8 \%)$ to distinguish the inheritable genetic parameter profiles.

Considering the results obtained in this quantitative genetics study, it was possible to determine which yield and nutritional components are important for maize breeding, to minimize the lack of information on the contribution of variance components, genetic parameters and heterosis for the half-sibling progenies, to gather univariate genetic parameters and to define multivariate profiles for narrow sense heritability. Therefore, it was possible to obtain relevant and applicable information for the genetic improvement of maize regarding selection for grain yield and nutritional quality.

Half-sibling progenies revealed greater additive genetic contribution to phenotypic expression through grain width and thickness, iron content, total flavonoids and carotenoids, soluble solids, and methionine. Narrow sense heritability values between and within progenies were higher for manganese content, glycine, proline and tryptophan. Regardless of the inbreeding line $\mathrm{S}_{5}$ used, heterosis gains were obtained for ear insertion height, number of grain rows per ear, stalk diameter, zinc content, total carotenoids, soluble solids and $\mathrm{pH}$. Specific heterosis was found for grain yield, glycine, serine, threonine and phenylalanine. The multivariate approach that we used defined eight-character profiles as a function of their genetic trends, and indicated narrow sense heritability of the progeny mean as the major cause for this distinction. These genetic parameters are essential and applicable to plant breeding, where they can assist the selection strategies for maize yield and nutritional components.

\section{REFERENCES}

Association of Official Analytical Chemists (AOAC) (2005). Official methods of analysis of the AOAC. Available at http://www.aoac.org/aoac_prod_imis/AOAC/Publications/Official_Methods_of_Analysis/AOAC_Member/Pubs/O MA/AOAC Official_Methods of Analysis.aspx.Accessed 17 March 2018.

Azmach G, Gedil M, Menkir A, Spillane C. (2013). Marker-trait association analysis of functional gene markers for provitamin A levels across diverse tropical yellow maize inbred lines. BMC Plant Biology.13:2-16.

Bernini CS, Paterniani MEAGZ, Duarte AP, Gallo PB, et al. (2013).Inbreeding depression and heterosis of hybrids in F2 populations of maize in the Sao Paulo State, Brazil.Bragantia.72: 217-223.

Brand Williams W, Cuvelier M, Berset C. (1995). Use of a Free Radical Method to Evaluate Antioxidant Activity. Food Sci. Technol.28: 25-30.

Carvalho IR, Nardino M, Pelegrin AJ, Ferrari M, et al. (2016). Path analysis and Annicchiarico method applied in relation to protein in corn (Zea mays L.) grains. AJBAS. 10:300-306. 
Carvalho IR, Nardino M, Pelegrin AJ, Hoffmann JF, et al. (2016). Estimates of genetic parameters in bioactive and micronutrients compounds of maize. AJAR.11: 3123-3133.

Cruz CD. (2013). GENES - A software package for analysis in experimental statistics and quantitative genetics. Acta Scientiarum.35: 271-276.

Cos RC, Moco S, Lommen A, Keurentjes JJ, et al. (2007). Untargeted large-scale plant metabolomics using liquid chromatography coupled to mass spectrometry. Nat Protoc.2:778-791.

Falconer DS, Mackay TFC.(1996). Introduction to quantitative genetics. $1^{\text {st }}$ edn.Longmans Green, London.

Faluba JS, Miranda GV, Lima RO, Souza LV, et al. (2010).Genetic potential of maize population UFV 7 for breeding in Minas Gerais. Cienc. Rural. 40: 1250-1256.

Galili GAD, Amir R and Alisdair RF. (2016).The regulation of essential amino acid synthesis and accumulation in plants.Annu. Rev. Plant Biol.67:153-178.

Hallauer AR, Miranda Filho JB. (1995). Quantitative Genetics in Maize Breeding. $1^{\text {st }}$ edition. Iowa State University Press. Ames.

Halilu AD, Ado SG, Aba DA and Usman IS.(2016) Genetics of carotenoids for provitamin a biofortification in tropicaladapted maize. Crop J.4:313-322.

Heinz R, De Sousa MLH, Gonçalves MC, Neto ALV, et al. (2012). Selection of half-sib of maize for nitrogen use efficiency. Rev. Ciênc. Agron. 43:731-739.

Nardino M, Baretta D, Carvalho IR, Follmann DN, et al. (2016). Phenotypic, genetic and environment correlation between traits of hybrid maize. Bras. J. Biometria. 34:379-394.

Palomino EC, Ramalho MAP, Ferreira DF. (2000). Sample size for half-sib family evaluation in maize. Pesq. Agropec. Bras.35:1433-1439.

Paterniani MEAGZ, Guimarães PDS, Lüders RR, Gallo PB, et al. (2008). Combining ability, genetic divergence among maize lines and correlation with heterosis. Bragantia.67:639-648.

Ramalho M, Santos JB, Pinto CB, Souza EA, et al. (2012). Genetics in the Agriculture. $4^{\text {th }}$ edn. UFLA press, Lavras.

Resende MDV, Duarte JB. (2007). Precision and quality control in variety trials. Pesq. Agrop. Tropical. 37:182-194.

Resende MDV. (2016). Software Selegen- REML/BLUP: A useful tool for plant breeding. Crop. Breed. Appl. Biotechnol.16:330-339.

Rios SDA, Alves KR, Costa NMB and Martino HSD.(2009). Biofortification: micronutrient enriched crops by genetic improvement. Ceres. 56: 713-718.

Rufino MSM. (2007). Determination of the total antioxidant activity in fuits by the ABTS free radical capture. $1^{\text {st }}$ edn.Embrapa press. Sete Lagoas.

Shapiro SS and Wilk MB. (1965). An Analysis of Variance Test for Normality. Biometrika.52:3-4.

Singleton VL and Rossi JA.(1965). Colorimetry of total phenolics with phosphomolybdic-phosphotungstic acid reagents.AJEV.16:144-158.

Singh D. (1981).The relative importance of characters affecting genetic divergence. Indian J. Genet. Pl. Br.41:237-245.

Souza VQ, Carvalho IR, Follmann DN, Nardino M, et al (2015). Defoliation and its effects on morphological and productive traits in maize hybrids. Rev. Bras. Milho e Sorgo 14: 61-74.

Szareski VJ, Carvalho IR, Kehl K, Pelegrin AJ, et al. (2018). Interrelations of Characters and Multivariate Analysis in Corn.J Agric Sci. 10: 187-194.

Szareski VJ, Carvalho IR, Kehl K, Levien AM, et al. (2017). Univariate, multivariate techniques and mixed models applied to the adaptability and stability of wheat in the Rio Grande do Sul State. Genet. Mol. Res.16:1-13.

Tedesco MJ, Gianello C, Bissani CA, Bohnen H, et al. (1995). Analysis of soil, plants and other materials. $1^{\text {st }}$ edn. UFRGS Prees, Porto Alegre.

Ufaz S and Galili G. (2008).Improving the content of essential amino acids in crop plants: goals and opportunities. Plant Physiol.147: 954-961.

Wen W, Li D, Li X, Gao Y, et al. (2014). Metabolome-based genome-wide association study of maize kernel leads to novel biochemical insights. Nat. Commun.5: 343-348.

Wen W, Brotman Y, Willmitzer L, Yan J. et al. (2016).Broadening Our Portfolio in the Genetic Improvement of Maize Chemical Composition. Trends Genet. 32: 459-469. 